\title{
DOSIS EFEKTIF ENOXAPARIN DALAM MENCEGAH TERJADINYA TROMBOSIS PADA ANASTOMOSIS ARTERI FEMORALIS TIKUS
}

\author{
I Made Suka Adnyana ${ }^{1}$, Iswinarno Doso Saputro ${ }^{2}$ \\ ${ }^{1}$ Program Pendidikan Dokter Spesialis Bedah Plastik Rekonstruksi dan Estetik, Fakultas Kedokteran Universitas \\ Airlangga, Surabaya, Indonesia. Korespondensi: madesukaadnyana@yahoo.com \\ ${ }^{2}$ Departemen Bedah Plastik Rekonstruksi dan Estetik, Rumah Sakit Umum Daerah Dr.Soetomo Surabaya, \\ Indonesia.
}

\begin{abstract}
ABSTRAK
Tujuan: untuk mengetahui dosis efektif enoxaparin dalam mencegah terjadinya trombosis pada anastomosis mikrovaskular. Metode: penelitian ini bersifat eksperimental dengan rancangan the randomized post test only control group design. Terdapat 33 tikus jantan Rattus norvegicus Wistar strain yang dikelompokkan menjadi tiga perlakuan yaitu perlakuan A (enoxaparin $0,75 \mathrm{mg} / \mathrm{kg}$ ), B (enoxaparin $1 \mathrm{mg} / \mathrm{kg}$ ), dan C (kontrol). Tuck model anastomosis dilakukan pada arteri femoralis, kemudian luas trombus yang terjadi pada pembuluh darah dibandingkan dengan diameter lumen pembuluh darah diukur dengan graticule lens dan dinyatakan dalam persen. Hasil: trombus terbentuk pada semua subyek penelitian baik pada kelompok perlakuan maupun kontrol. Rerata persentase luas trombus pada kelompok enoxaparin $0,75 \mathrm{mg} / \mathrm{kg}$ adalah $24,3 \%$, enoxaparin $1 \mathrm{mg} / \mathrm{kg}$ sebesar $19,8 \%$ dan kelompok $\mathrm{NaCl}$ 0,9\% sebesar 79,4\%. Terdapat perbedaan antara perlakuan pemberian enoxaparin dosis $0,75 \mathrm{mg} / \mathrm{kg}$ dan $1 \mathrm{mg} / \mathrm{kg}$ dengan kontrol, namun tidak ada perbedaan bermakna rerata persentase luas trombus diantara kelompok enoxaparin dosis $0,75 \mathrm{mg} / \mathrm{kg}$ dan dosis $1 \mathrm{mg} / \mathrm{kg}(\mathrm{p}=0,624)$. Perlu dilakukan penelitian secara klinis guna melihat efektivitas enoxaparin dalam meningkatkan patensi anastomosis pada free flap maupun replantasi. Simpulan: pemberian enoxaparin dosis $0,75 \mathrm{mg} / \mathrm{kg}$ dan enoxaparin dosis $1 \mathrm{mg} / \mathrm{kg}$ secara subkutan efektif mengurangi persentase luas trombus pada anastomosis arteri femoralis tikus. Tidak terdapat perbedaan efektivitas yang bermakna dalam mengurangi persentase luas trombus pada anastomosis arteri femoralis tikus setelah diberikan dosis enoxaparin $0,75 \mathrm{mg} / \mathrm{kg}$ dan 1 $\mathrm{mg} / \mathrm{kg}$ secara subkutan.
\end{abstract}

Kata kunci: anastomosis, enoxaparin, free flap, trombosis.

\section{EFFECTIVE DOSE OF ENOXAPARIN IN PREVENTING THROMBOSIS OF FEMORAL ARTERY ANASTOMOSIS IN RATS}

\author{
I Made Suka Adnyana ${ }^{1}$, Iswinarno Doso Saputro ${ }^{2}$ \\ ${ }^{1}$ Plastic Reconstructive and Esthetic Surgery Training Program, Faculty of Medicine, Airlangga University, \\ Surabaya, Indonesia. \\ ${ }^{2}$ Plastic Reconstructive and Esthetic Surgery Department, Dr.Sutomo General Hospital, Surabaya, Indonesia.
}

\begin{abstract}
Objective: to investigate the effective dose enoxaparin in preventing the occurrence of thrombosis in microvascular anastomosis. Methods: this study is a randomized experimental study with the posttest only control group design. There were 33 male rats Rattus norvegicus Wistar strain were grouped into three treatments, treatment A (enoxaparin $0.75 \mathrm{mg} / \mathrm{kg}$ ), B (enoxaparin $1 \mathrm{mg} / \mathrm{kg}$ ), and C (control). Femoral artery tuck model anastomoses were performed in this study, later comparison between the board occurrence of thrombus in blood vessel and lumen diameter was measured using a graticule lens and the result in percent. Results: thrombus was found in entire subject in this study whether in treatment group or the control. We found the mean percentage of thrombosis in enoxaparin $0.75 \mathrm{mg} / \mathrm{kg}$
\end{abstract}


group was $24.3 \%$, enoxaparin $1 \mathrm{mg} / \mathrm{kg}$ group was $19.8 \%$ and in the $\mathrm{NaCl} 0.9 \%$ group was $79.4 \%$. There are differences between the treatment dose administration of enoxaparin $0.75 \mathrm{mg} / \mathrm{kg}$ and $1 \mathrm{mg} / \mathrm{kg}$ with controls, but no significant difference between the mean percentage of thrombus extensive group of enoxaparin dose of $0.75 \mathrm{mg} / \mathrm{kg}$ and a dose of $1 \mathrm{mg} / \mathrm{kg}$ ( $\mathrm{p}=0.624)$. Clinical studies are necessary to see the effectiveness of enoxaparin in increasing the patency of the free flap anastomosis or replanted.

Conclusion: administration of enoxaparin dose of $0.75 \mathrm{mg} / \mathrm{kg}$ and enoxaparin dose of $1 \mathrm{mg} / \mathrm{kg}$ subcutaneously effectively reduce the percentage of extensive thrombus in rat femoral artery anastomosis. There were no significant differences in effectiveness in reducing the percentage of extensive thrombus in rat femoral artery anastomosis after being given a dose of enoxaparin $0.75 \mathrm{mg} / \mathrm{kg}$ and $1 \mathrm{mg} / \mathrm{kg}$ subcutaneously

Keywords: anastomosis, enoxaparin, free flap, thrombosis.

\section{PENDAHULUAN}

Free flap dengan anastomosis pembuluh darah sangat populer untuk rekonstruksi pada daerah kepala dan leher maupun daerah yang lain. Free flap memiliki keunggulan dibandingkan teknik konvensional, karena tingkat keberhasilan free flap yang dilaporkan yaitu sekitar 95\%. ${ }^{1}$ Angka eksplorasi ulang yang dilaporkan sebagai usaha untuk menyelamatkan flap sekitar $6 \%-25 \% .^{2,3}$ Trombosis merupakan permasalahan yang paling sering ditemukan. Mencegah terjadinya trombosis lebih penting, daripada melakukan eksplorasi ulang dan thrombectomy, pencegahan dapat dilakukan dengan memperhatikan teknik operasi dan juga menggunakan obatobatan. ${ }^{1,4}$ Strategi farmakologi yang dapat dilakukan untuk mencegah terjadinya trombosis yaitu dengan pemberian obatobatan antitrombosis seperti heparin, tetapi heparin sering mengakibatkan peningkatan waktu perdarahan, perdarahan hematom pada flap, maupun komplikasi sistemik yang lain. ${ }^{1,5}$

Low molecular weight heparin (LMWH) merupakan derivat heparin dengan sifat antitrombosis seperti heparin tetapi tidak mengganggu waktu perdarahan secara keseluruhan. ${ }^{6,7}$ Enoxaparin merupakan salah satu LMWH, yang bekerja dengan cara meningkatkan aktivitas antitrombin III, menghambat faktor koagulasi Xa dan IIa, serta menunjukkan penurunan kejadian trombosis vena pada penderita yang berisiko terjadinya deep vein trombosis. Pada penelitian hewan dan manusia, enoxaparin dan heparin memiliki efektifitas yang sama dalam mencegah trombosis vena dan arterial, tetapi komplikasi perdarahan yang ditimbulkan oleh enoxaparin lebih sedikit. ${ }^{1,8}$ Enoxaparin digunakan sebagai profilaksis terjadinya trombosis pada operasi anastomosis pembuluh darah. Hadlock, et al menemukan bahwa enoxaparin dengan dosis $50 \mathrm{IU} / \mathrm{kg}(0,5$ $\mathrm{mg} / \mathrm{kg}$ ) tidak menunjukkan perbedaan yang signifikan dengan kontrol dalam mencegah terjadinya trombosis. ${ }^{1}$ Penelitian ini meneliti dosis efektif enoxaparin dalam mencegah terjadinya trombosis pada anastomosis arteri tikus dengan menaikkan dosis menjadi $0,75 \mathrm{mg} / \mathrm{kg}$ dan $1 \mathrm{mg} / \mathrm{kg}$. Dosis lazim yang digunakan untuk profilaksis deep vein trombosis (DVT) dalam pembedahan sekitar 0,5-0,75 $\mathrm{mg} / \mathrm{kg}$ setiap kali injeksi subkutan dan dapat diberikan 1-2 kali/hari. Terapi DVT diberikan 1-1,5 $\mathrm{mg} / \mathrm{kg}$ diberikan 1-2 kali/hari. ${ }^{9}$ 


\section{METODE}

Rancangan penelitian ini adalah the randomized post test only control group design. Hewan coba yang digunakan adalah tikus jantan Rattus norvegicus Wistar strain. Replikasi pada setiap kelompok adalah $\geq 9$, karena tiga kelompok perlakuan, maka total hewan coba $\geq 27$.

Tikus yang dipilih dibagi menjadi tiga kelompok yaitu kelompok perlakuan A (enoxaparin $0,75 \mathrm{mg} / \mathrm{kg}$ ), B (enoxaparin 1 $\mathrm{mg} / \mathrm{kg}$ ), dan C (kontrol) dilakukan secara random, serta operator dan analis data tidak mengetahui perlakuan yang diberikan pada tikus (blind). Setelah dua jam perlakuan, dilanjutkan dengan melakukan tuck model anastomosis pada arteri femoralis, dilakukan reseksi $2 \mathrm{~mm}$ proksimal dan distal dari anastomosis. Luas trombus yang terjadi pada pembuluh darah dibandingkan dengan diameter lumen pembuluh darah diukur dengan graticule lens dan dinyatakan dalam persen.

Data yang dikumpulkan dianalisis menggunakan statistik deskriptif dan inferensial. Uji yang digunakan adalah uji ANOVA (Analysis of Variate), dilanjutkan dengan uji komparasi ganda yaitu Least Square Differences (LSD).

\section{HASIL}

Sampel penelitian ini adalah 33 ekor tikus, yang dikelompokkan menjadi 3 yaitu kelompok A yang mendapat dosis 0,75 $\mathrm{mg} / \mathrm{kg}$, kelompok B mendapat dosis 1 $\mathrm{mg} / \mathrm{kg}$, dan kelompok C sebagai kontrol. Pada pengecatan hematoxylin dan eosin (H\&E) diidentifikasi adanya trombus yang terbentuk pada lumen pembuluh darah. Pembuluh darah secara keseluruhan dapat dilihat dengan menggunakan pembesaran 100 kali (gambar 1) dan pengukuran luas trombus dilakukan pada pembesaran 400 kali (gambar 2).

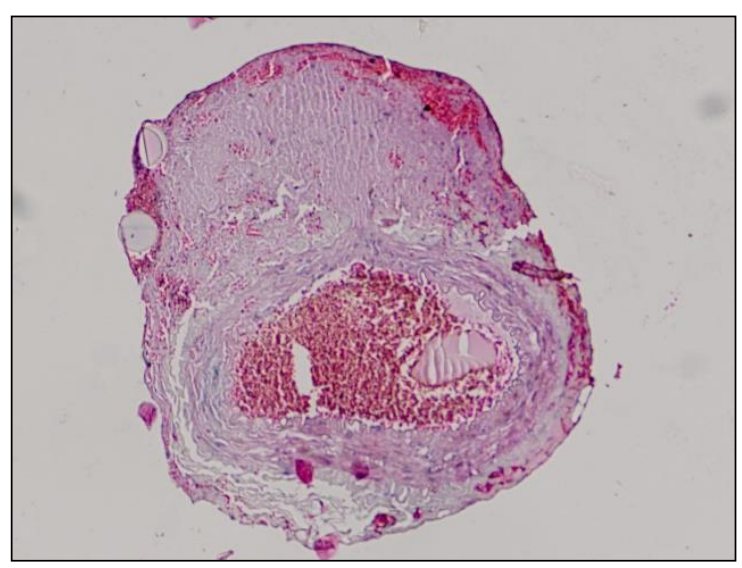

Gambar 1. Penampang pembuluh darah dengan pembesaran 100 kali

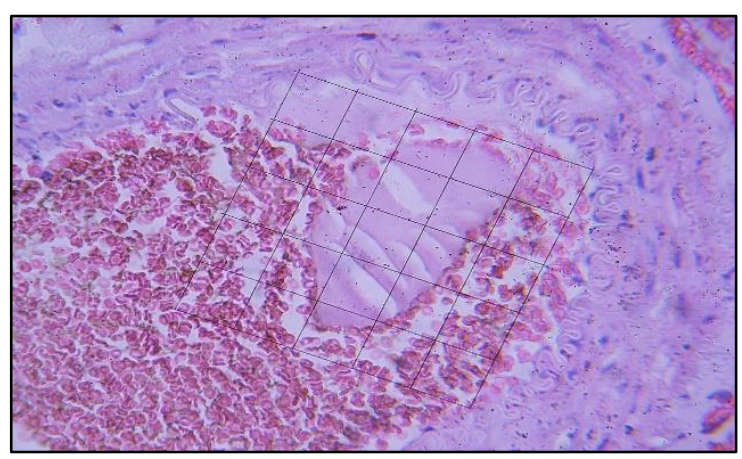

Gambar 2. Penampang pembuluh darah dan trombus yang terbentuk dengan kotak graticule pada pembesaran 400 kali

Rerata persentase luas trombus dibandingkan luas lumen pembuluh darah pada kedua kelompok enoxaparin dan kontrol, menunjukkan rerata persentase luas trombus paling kecil pada kelompok enoxaparin $1 \mathrm{mg} / \mathrm{kg}$ (19,8\%), kemudian disusul oleh kelompok enoxaparin 0,75 $\mathrm{mg} / \mathrm{kg}(24,3 \%)$ dan kelompok kontrol $(79,4 \%)$ (tabel 1). Hasil perhitungan ANOVA didapatkan nilai $p<0,0001$, hal ini menunjukkan terdapat perbedaan bermakna rerata persentase luas trombus antar kelompok perlakuan. 
Tabel 1. Analisis statistik persentase luas trombus

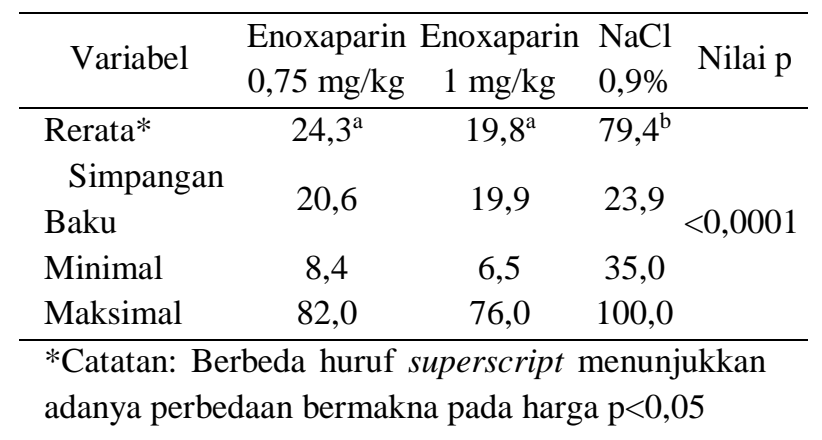

Hasil uji komparasi ganda dengan Least Square Differences (LSD) diperoleh perbedaan bermakna antara kelompok kontrol dan kelompok enoxaparin 0,75 $\mathrm{mg} / \mathrm{kg} \quad(\mathrm{p}<0,0001)$, begitu pula dengan kelompok kontrol dan kelompok enoxaparin $1 \mathrm{mg} / \mathrm{kg}(\mathrm{p}<0,0001)$. Namun tidak ada perbedaan bermakna antara rerata persentase luas trombus diantara kelompok enoxaparin dosis $0,75 \mathrm{mg} / \mathrm{kg}$ dan dosis 1 $\mathrm{mg} / \mathrm{kg}(\mathrm{p}=0,624)$.

\section{DISKUSI}

Penelitian ini menunjukkan LMWH sangat potensial bila digunakan sebagai profilaksis terbentuknya trombus dalam anastomosis mikrovaskular dengan kemungkinan komplikasi pendarahan yang lebih sedikit. Penelitian ini menunjukkan antara kelompok enoxaparin $0,75 \mathrm{mg} / \mathrm{kg}$ dan enoxaparin $1 \mathrm{mg} / \mathrm{kg}$ tidak didapatkan perbedaan persentase luas trombus yang signifikan. Hal ini mungkin disebabkan karena perbedaan dosis yang diberikan pada kedua kelompok enoxaparin tidak telalu besar. Penelitian sebelumnya menemukan efek enoxaparin $0,5 \mathrm{mg} / \mathrm{kg}$ yang diberikan secara subkutan dalam mencegah trombosis pada anastomosis mikroarterial dengan menggunakan model tikus. Mereka tidak menemukan adanya perbedaan kejadian trombus antara kelompok kontrol dan perlakuan secara bermakna. Dosis yang digunakan oleh Hadlock merupakan dosis terendah dari dosis yang dianjurkan sebagai profilaksis. ${ }^{1}$

Stepnick menemukan bahwa trombus yang terbentuk terdiri platelet dan fibrin, dengan komponen platelet lebih dominan. ${ }^{10}$ Meskipun demikian, peranan fibrin dalam pembentukan trombus juga sangat penting. Pada penelitian ini dapat dilihat bahwa dengan dihambatnya faktor Xa pada sistem koagulasi oleh enoxaparin dapat menurunkan luas trombus yang terbentuk, terbukti pada kedua kelompok yang diberikan enoxaparin menunjukkan rerata persentase luas trombus yang lebih rendah dibandingkan dengan kontrol. ${ }^{10}$ Hal tersebut serupa dengan hasil yang diperoleh dalam penelitian ini yaitu rerata persentase luas trombus pada kelompok enoxaparin $0,75 \mathrm{mg} / \mathrm{kg}$ sebesar $24,3 \%$, enoxaparin 1 $\mathrm{mg} / \mathrm{kg}$ sebesar 19,8\%, dan kelompok kontrol sebesar 79,4\%, dan terdapat perbedaan antara kelompok kontrol dengan kelompok perlakuan.

\section{SIMPULAN}

Pemberian enoxaparin dosis $0,75 \mathrm{mg} / \mathrm{kg}$ dan enoxaparin dosis $1 \mathrm{mg} / \mathrm{kg}$ secara subkutan efektif mengurangi persentase luas trombus pada anastomosis arteri femoralis tikus. Tidak terdapat perbedaan efektivitas yang bermakna dalam mengurangi persentase luas trombus pada anastomosis arteri femoralis tikus setelah diberikan dosis enoxaparin $0,75 \mathrm{mg} / \mathrm{kg}$ dan $1 \mathrm{mg} / \mathrm{kg}$ secara subkutan.

\section{DAFTAR PUSTAKA}

1. Hadlock TA, Kim J, Deschler DG. The Effect of Subcutaneously Administered Low-Molecular-Weight Heparin on Microarterial Trombosis in the Rat. Archive Facial Plastic Surgery. 2003;5:36-9. 
2. Jones NF. Intraoperative and postoperative monitoring of microsurgical free tissue transfers. Clin Plast Surg. 1992;19:783-97.

3. de Weerd L, Mercer JB, Setså LB. Intraoperative Dynamic Infrared Thermography and Free-Flap Surgery. Ann Plast Surg. 2006;57: 279-84.

4. Vijay K, Nayak, Deschler DG. Clopidogrel Use for Reducing the Rate of Trombosis in a Rat Model of Microarterial Anastomosis. Archive of Otolaryngology-Head and Neck Surgery. 2009;131:800-3.

5. Salzman EW, Deykin D, Shapiro RM, et al. Management of heparin therapy: controlled prospective trial. $N$ Engl $J$ Med. 1975;292:1046-50.

6. Zhang B, Wieslander J. Improvement of patency in small veins following dextran and/or low-molecular-weight heparin treatment. Plast Reconstr Surg. 1994;94:352-8.

7. Gerlach AT, Pickworth KK, Seth SK, et al. Enoxaparin and bleeding complications: a review in patients with and without renal insufficiency. Pharmacotherapy. 2000;20:771-5.

8. Samama CM, Gigou F, III P for the Enoxart study group. Low-molecularweight heparin vs. unfractionated heparin in femorodistal reconstructive surgery: a multicenter open randomized study. Ann Vasc Surg. 1995;9:S45-53.

9. Hirsch J, Theodore E, Warkentin, et al. Heparin and Low-molecular-weight heparin. Chest. 2001;119:188-202.

10. Stepnick DW, Hayden RE, Hogikyan ND. Developement of Thrombosis Model in the Rabbit. Arch Otolaryngol Head Neck Surg. 1994;120:997-1002. 